\title{
Catalytic Dehydrogenation of Ethane: A Mini Review of Recent Advances and Perspective of Chemical Looping Technology
}

\author{
Danis Fairuzov, Ilias Gerzeliev, Anton Maximov and Evgeny Naranov *(D) \\ Topchiev Institute of Petrochemical Synthesis, Russian Academy of Sciences, Leninskiy Prospect, 29, \\ 119991 Moscow, Russia; 60fdh@mail.ru (D.F.); gerzeliev@ips.ac.ru (I.G.); max@ips.ac.ru (A.M.) \\ * Correspondence: naranov@ips.ac.ru
}

\begin{abstract}
Dehydrogenation processes play an important role in the petrochemical industry. High selectivity towards olefins is usually hindered by numerous side reactions in a conventional cracking/pyrolysis technology. Herein, we show recent studies devoted to selective ethylene production via oxidative and non-oxidative reactions. This review summarizes the progress that has been achieved with ethane conversion in terms of the process effectivity. Briefly, steam cracking, catalytic dehydrogenation, oxidative dehydrogenation (with $\mathrm{CO}_{2} / \mathrm{O}_{2}$ ), membrane technology, and chemical looping are reviewed.
\end{abstract}

Keywords: ethylene; ethane; dehydrogenation; cracking; membrane technology; chemical looping

Citation: Fairuzov, D.; Gerzeliev, I.; Maximov, A.; Naranov, E. Catalytic Dehydrogenation of Ethane: A Mini Review of Recent Advances and Perspective of Chemical Looping Technology. Catalysts 2021, 11, 833. https://doi.org/10.3390/ catal11070833

Academic Editor: Vladimir Galvita

Received: 31 May 2021

Accepted: 7 July 2021

Published: 9 July 2021

Publisher's Note: MDPI stays neutral with regard to jurisdictional claims in published maps and institutional affiliations.

Copyright: (C) 2021 by the authors. Licensee MDPI, Basel, Switzerland. This article is an open access article distributed under the terms and conditions of the Creative Commons Attribution (CC BY) license (https:// creativecommons.org/licenses/by/ $4.0 /)$.

\section{Introduction}

Ethylene is one of the most critical intermediates in the petrochemical industry and the global demand for this chemical is shown in Figure 1; it is currently produced through the steam cracking of light hydrocarbon derivatives, mainly ethane and naphtha [1-3]. Ethylene complexes operate in 57 countries of the world. There are 215 ethylene producing facilities operating in the world. The operators of these complexes are about 100 companies, and the largest are ExxonMobil, SABIC, DowDuPont [4-6]. The world's largest concentration of ethylene production capacity is located in the four main regions of North America, Northeast Asia, Central Asia, and Western Europe. Moreover, the main production growth will be observed only in North America and Northeast Asia. The main reason for the growth in ethylene production in Northeast Asia is the demand for ethylene processing products in China (primarily polyethylene for packaging goods) [7-9]. The greatest development of ethylene production in 2010-2020 observed in the Asia-Pacific countries and in the Middle East, where their own cheap raw materials are used, mainly gas [10]. The ethylene pyrolysis capacity in these regions increased 2.1 and 5.3 times, respectively [11].

An important trend in the current decade was the increase in pyrolysis capacity in North America, which in the period under review increased by almost $25 \%$, which was the result of the shale gas revolution in the United States [1,6]. The European olefin market is stagnating due to the loss of competitiveness of the naphtha-based products produced by the regional enterprises and the presence of a large number of old plants. As a result, this period saw the closure of a significant volume of production in Western Europe, which was also associated with the deterioration of conditions for the petrochemical business in the region due to higher taxes and tightening of environmental requirements in European countries.

The expansion of pyrolysis capacities is cyclical: active development in 2000-2010 with an average annual growth of more than $4 \%$ per year, in the first half of the current decade it was replaced by a small volume of new construction. Since 2018, a wave of creation of new and expansion of existing pyrolysis units began. Currently, the construction of 116 new production facilities has been announced. If all projects are implemented, in the long term, until 2026, there will be an increase in the total world capacity of pyrolysis 
plants for ethylene by more than $41 \%$ to 260 million tons per year [12,13]. In the future, Iran plans to increase pyrolysis capacity, the country has announced until 2023 the construction of 17 new installations with a capacity of 10.9 million tons per year, capital investments will amount to USD 6.69 billion. Plans are in place for nearly a third of all new ethylene facilities to be built in China over the next ten years [11]. Until 2021 alone, the country plans to build 29 production facilities with a total capacity of 14.5 million tons per year. Capital expenditures should amount to USD 9.05 billion [10,14]. An important feature of the upcoming development of the olefins market is the activation of the United States of America (USA) in this area [15]. Providing pyrolysis plants with their own shale feedstock has made ethylene production in the United States extremely profitable and highly competitive in the world market [16]. Until 2027, it is planned to build 17 pyrolysis plants in the USA with a total capacity of 19.9 million tons per year. Planned capital expenditures should amount to USD 22.03 billion. In addition, ethylene facilities with a total capacity of about 13 million tons per year are in the planning stage. According to experts, there is not enough ethane in the United States to implement all these plans, as a result of which, many projects will not be implemented or will be able to operate on other raw materials, which will reduce their profitability [17]. There are projects for the construction of pyrolysis plants even in South America and Africa: Venezuela and Bolivia plan to build a joint production facility with a capacity of 1.4 million tons per year by 2023 . The investment is estimated at USD 1.06 billion. The construction of a plant with a capacity of 1.7 million tons per year has been announced in Egypt with capital expenditures of USD 4.55 billion.

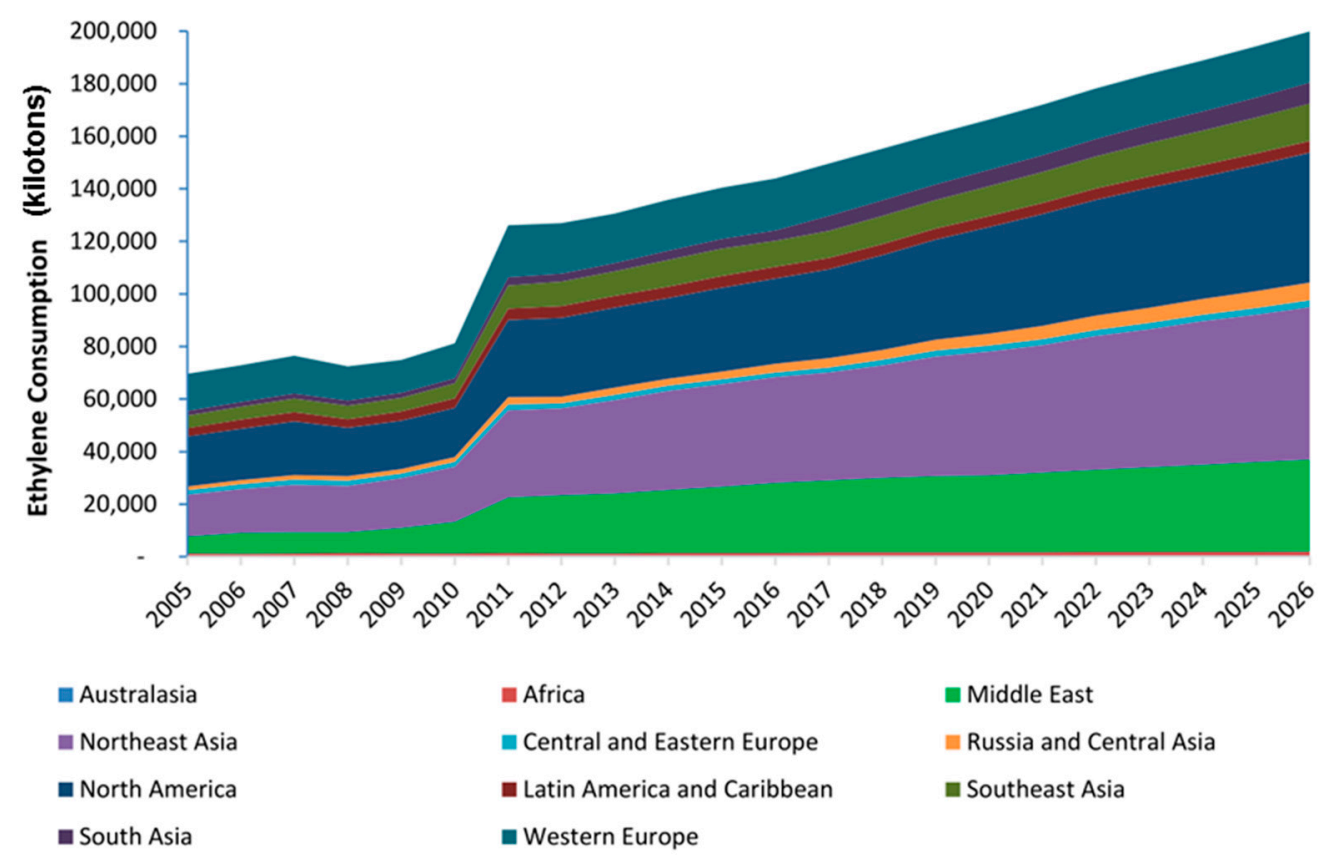

Figure 1. Global ethylene demand is expected to grow to almost 200 megatons by 2026.

Although there have been quite a lot of excellent reviews covering the topic of ethylene production, they tend to focus on cracking processes, and in some cases, oxidative dehydrogenation [1-7]. This review aims to offer a perspective on various processes of selective ethylene production and the generalized design principles for the oxidative processes. This review aims to summarize recent progress in ethylene production with the focus on novel approaches.

\section{Steam Cracking Process}

Steam cracking process produces about $>140$ megatons of ethylene per year, converting ethane to ethylene through a single-pass yield of approximately $50 \%$ at high temperatures 
(up to $1100{ }^{\circ} \mathrm{C}$ ) $[2,18]$. High ethylene yield is limited due to endothermic cracking reactions. Since the cracking process is both energy and pollutant intensive and suffers from the coke formation, it requires periodic shut down of cracker furnaces for coke burnout. Production of 1 ton of ethylene requires $16 \mathrm{GJ}$ of thermal energy and results in approximately 1.2 tons of $\mathrm{CO}_{2}$ emissions. The steam cracking process is energy-intensive, consuming $40 \%$ of the total energy in the chemical and petrochemical industry [6]. When ethane is used as the feed, the steam cracking process is driven by the ethane cracking reaction. Because ethane steam cracking produces a wide product distribution, a cryogenic distillation train is necessary to obtain pure ethylene [19]. To obtain ethylene from ethane steam cracking requires upstream separation to obtain the ethane feed and downstream separation for ethylene [2]. Ethylene can be produced from light hydrocarbons $\left(\mathrm{CH}_{4}, \mathrm{C}_{2} \mathrm{H}_{6}\right.$, and naphtha) through the thermochemical routes and oxidative routes $[5,6]$. The thermochemical routes for ethylene production include methane coupling and thermal cracking. These processes are thermodynamically limited, although such limitations can be alleviated by increasing the operating temperature, as the equilibrium constant for ethylene formation from methane is only 0.272 at $1200^{\circ} \mathrm{C}$ and $1 \mathrm{~atm}$. [6]. The overall enthalpy of the processes $(\Delta \mathrm{H})$ can be of critical importance for reactor design. Unlike the Gibbs energy values, the heat of reaction is not a strong function of operating temperature (Table 1). That is why an endothermic steam cracking process operated at lower temperatures that consumes low-grade heat or an exothermic process carried out at relatively high temperatures that generates high-grade heat would offer a better opportunity for efficiency improvements on the basis of ease in heat integration and thermodynamic second law analysis [20].

Table 1. Reaction enthalpy of ethylene production by different processes at $600\left({ }^{\circ} \mathrm{C}\right), \mathrm{kJ} / \mathrm{mol}$.

\begin{tabular}{cccc}
\hline Process & $\begin{array}{c}\text { Oxidative Dehydrogenation of } \\
\text { Ethane }\end{array}$ & $\begin{array}{c}\text { Oxidative Dehydrogenation of } \\
\text { Ethane with } \mathrm{CO}_{2}\end{array}$ & $\begin{array}{c}\text { Nonoxidative } \\
\text { Dehydrogenation of Ethane }\end{array}$ \\
\hline$\Delta \mathrm{H}$ & -103 & 178 & 142 \\
\hline
\end{tabular}

The development of the steam cracking process plant started a century ago and its understanding has evolved from an empirical description to a detailed knowledge of its fundamentals, in terms of chemical mechanism, kinetics, process requirements, design methods, etc., Van Goethem et al. have given an overview of the various options for this process [21]. The steam cracking technology has reached a stage of maturity in which improvements in yield and product selectivity are becoming increasingly difficult due to engineering restrictions. Typically, the ethylene yields are improved by raising the cracking temperature and reducing residence time, in other words increasing the process severity [22].

\section{Catalytic Ethane Dehydrogenation}

Formation of side products such as aromatics, light gaseous hydrocarbons is unavoidable when cracking/pyrolysis is used [1]. Fabrication of methane, light hydrocarbons $\mathrm{C}_{2}-\mathrm{C}_{4}$, and aromatics during the process is especially sustainable at high temperatures. This side process decreases the efficiency for ethylene production [14]. Catalytic conversion of ethane to ethylene is expected as a solution to those problems. Non-oxidative catalytic ethane dehydrogenation over oxide or supported-metal catalysts has been investigated widely to achieve environmentally friendly ethylene production. Catalytic ethane dehydrogenation, denoted as EDH, enables ethylene production at lower temperatures than those of pyrolysis of ethane. However, the reaction is endothermic [3]. That is why, in this process, a high temperature and low pressure of ethane must be used and to achieve higher ethane conversion. The catalysts should possess the ability of selective $\mathrm{C}-\mathrm{H}$ bond break. The side processes like hydrogenolysis and polymerization of ethylene to coke must be avoided to achieve high selectivity towards ethylene. Table 2 summarizes the process conditions and performances. 
The Pt, Pd containing systems are common catalysts for the selective dehydrogenation of hydrocarbons. The ethane conversion over noble metal catalysts conducts at low temperatures [23-25]. Two active sites are known for Pt-containing catalysts: octahedrally substituted Pt located at terrace sites and coordinative unsaturated Pt such as step and edge sites. Both active sites are responsible for the $\mathrm{C}-\mathrm{H}$ bond dissociation. However, the unsaturated Pt could induce side processes such as hydrogenolysis of ethane and subsequent polymerization to coke. Wu et al. showed that the selectivity towards ethylene was nearly constant, indicating that EDH proceeds at the terrace sites [26]. The turn over frequency increased with the increasing of Pt size, whereas in case for propane dehydrogenation, TOF decreases with increased Pt particle size. Galvita et al. demonstrated the benefit from co-feeding of $\mathrm{H}_{2}$ on catalytic stability, but selectivity towards ethylene decreases during the process [27]. Among these metals, gold containing catalysts also exhibit the catalytic activity for EDH [28]. It was shown that the catalyst Au-Si doped with Ti exhibited the dehydrogenation activity with conversion of $16 \%$ and the selectivity towards ethylene $95 \%$.

Due to high cost of those catalysts Ni-Ga alloys, which exhibited comparable catalytic performance of EDH to noble metal catalysts, they were found to be good candidates to replace expensive catalysts. Gallium oxide based on zeolites was used for the conversion of light alkanes. This reaction was used in the Cyclar process developed by BP/UOP [29,30]. The other successful substitution of noble metal catalysts are chromium-containing materials. Chromium oxide materials are known as high active catalysts of dehydrogenation of light alkanes, moreover, they are used in the Catofin process (Mcdermott-Lummus) [31].

Lanthanum manganite $\left(\mathrm{LaMnO}_{3}\right)$ perovskites are known for the activity in the oxidation processes. Yang et al. showed $\mathrm{EDH}$ over perovskite $\mathrm{LaMnO}_{3}$ with $\mathrm{Ni}$ additives [32]. They found that the proportion of $\mathrm{Mn}^{4+}$ increases and that Ni nanoparticles are deposited after reduction treatment with $\mathrm{H}_{2}$. Thus, they proposed that ethane dehydrogenation occurs on oxygen vacancies around $\mathrm{Mn}^{4+}$ and Ni nanoparticles. Sekine and co-workers investigated EDH with the presence of water over Ba-doped $\mathrm{LaMnO}_{3}[33,34]$. They demonstrated that dehydrogenation is promoted in the presence of steam because the reaction proceeds via the Mars-van Krevelen mechanism.

Table 2. Catalytic performance of EDH.

\begin{tabular}{ccccc}
\hline Catalyst & Temperature $\left({ }^{\circ} \mathbf{C}\right)$ & $\begin{array}{c}\text { Conversion } \\
\text { (wt. \%) }\end{array}$ & Selectivity (\%) & Reference \\
\hline $\mathrm{Pt}-\mathrm{Sn} / \mathrm{MgO}$ & 600 & 3 & 100 & {$[23]$} \\
$\mathrm{Pt}-\mathrm{In} / \mathrm{SiO}_{2}$ & 600 & 15 & 99 & {$[24]$} \\
$\mathrm{Au} / \mathrm{SiO}_{2}$ & 650 & 16 & 95 & 94 \\
$\mathrm{Ni}-\mathrm{Ga}_{2} \mathrm{Al}_{2} \mathrm{O}_{3}$ & 600 & 10 & 98 & {$[28]$} \\
$\mathrm{Cr}_{2} \mathrm{O}_{3} / \mathrm{SiO}_{2}$ & 650 & 19 & 93 & {$[31]$} \\
$\mathrm{Ga}_{2} \mathrm{O}_{3} / \mathrm{Al}_{2} \mathrm{O}_{3}$ & 650 & 28 & 72 & {$[35]$} \\
$\mathrm{Fe} / \mathrm{ZSM}-5$ & 600 & 22 & & {$[36]$} \\
\hline
\end{tabular}

\section{Oxidative Dehydrogenation in the Presence of Oxygen Gas}

The oxidative dehydrogenation $(\mathrm{ODH})$ reaction takes place in the presence of oxygen in the temperature range $300-700{ }^{\circ} \mathrm{C}$ and atmospheric pressure using appropriate catalysts. Typically, V, Mo and La containing catalysts are used in this process [37-41]. The reaction occurs through the partial oxidation forming ethylene and water in the temperature range of $400-700^{\circ} \mathrm{C}$. The exothermic ODH reaction combined with lower operating temperature requirements can result in energy savings by a quarter compared to a traditional steam cracking process. In addition, the ODH process leads to a decrease in the number of technological operations compared to the steam cracking process [42]. Table 3 summarizes the process conditions and performances.

The reduction in the number of plant operations is due to the excellent selectivity for ethylene ( $>98 \%)$ and $\mathrm{CO}_{2}$, which can be removed using membranes [43]. Therefore, additional expenses related to distillation equipment can be avoided. It should be noted that 
the coke formation problem is resolved due to the oxidative atmosphere, also preventing the reactivation steps. However, there are some unsolved problems that hinder the widespread introduction of oxidative dehydrogenation [44]. For example, the ODH reaction requires an inert atmosphere to keep the reaction mixture from entering the ignition conditions. The process uses ethane, highly diluted with inert gases (for example, nitrogen, argon, or helium) with a relatively low ethane partial pressure reducing the efficiency of the process. A feasibility study shows that the use of inert gases not only increases the size of equipment, thereby increasing capital costs, but also increases the risk of security threats [45].

Table 3. Catalytic performance of the different membrane-based ethane ODH.

\begin{tabular}{|c|c|c|c|c|}
\hline Membrane Type & Temperature $\left({ }^{\circ} \mathrm{C}\right)$ & $\begin{array}{l}\text { Ethane Conversion } \\
\text { (wt.\%) }\end{array}$ & $\begin{array}{l}\text { Ethylene Selectivity } \\
(\%)\end{array}$ & Reference \\
\hline $\mathrm{Ni}-\mathrm{Mg}$ & 600 & 69 & 53 & [46] \\
\hline $\mathrm{Ni}-\mathrm{Nb}$ & 400 & 45 & 76 & [40] \\
\hline Carbon nanotubes & 400 & 20 & 60 & [47] \\
\hline $\mathrm{Ni}-\mathrm{W}-\mathrm{Ti}$ & 330 & 40 & 70 & [48] \\
\hline Mg-Dy-Li & 600 & $20-90$ & $60-95$ & [49] \\
\hline Boron nitride & 590 & 11 & 95 & [44] \\
\hline V-Mo-Al & 580 & $20-40$ & $40-80$ & [41] \\
\hline
\end{tabular}

\section{Oxidative Dehydrogenation of Ethane in the Presence of $\mathrm{CO}_{2}$}

The ODH processes with the presence of gaseous oxygen cannot compete with the traditional processes of pyrolysis and steam cracking because of the expensive apparatus devoted to gaseous oxygen, which requires high tech reactors and a suitable diluent to ensure operational safety [50]. The other approach is to replace oxygen with carbon dioxide. Carbon dioxide is an oxidizing agent that prevents the complete oxidation of ethylene due to the lower oxidative ability compared to $\mathrm{O}_{2}$. Unlike the steam used in cracking processes, the use of $\mathrm{CO}_{2}$ in $\mathrm{ODH}$ of ethane can also be more attractive from both economic and environmental points of view [51,52]. The advantage of $\mathrm{ODH}-\mathrm{CO}_{2}$ is that it consumes the by-product of ethane dehydrogenation $-\mathrm{H}_{2}$ through the reverse water-gas shift reaction. This can shift the thermal equilibrium conditions for the dehydrogenation of ethane, which leads to a higher conversion of ethane to ethylene [53]. Table 4 summarizes the process conditions and performances. However, the $\mathrm{ODH}-\mathrm{CO}_{2}$ process has a number of problems: (1) $\mathrm{CO}_{2}$ must be separated from the gas streams; (2) $\mathrm{CO}_{2}$ conversion is generally low $(<50 \%)$, which leads to an increase in the cost of splitting the effluent stream; (3) Just like steam cracking, the ODH-CO 2 process is highly endothermic (Table 1). All this will lead to increased operating costs.

Typically, the reaction of $\mathrm{ODH}$ using $\mathrm{CO}_{2}$ occurs in a temperature range of $550-850{ }^{\circ} \mathrm{C}$ and atmospheric pressure using appropriate catalysts [54,55]. Consequently, innovative high activity catalysts are still under development. Since the ODH using $\mathrm{CO}_{2}$ is endothermic and $\mathrm{ODH}$ with $\mathrm{O}_{2}$ is highly exothermic, the heat exchange synergy of those two processes can be used to reduce the limitations. This process could provide an effective way to produce ethylene with low energy consumption [56].

Table 4. Catalytic performance of the different $\mathrm{ODH}-\mathrm{CO}_{2}$ processes.

\begin{tabular}{ccccc}
\hline Membrane Type & Temperature $\left({ }^{\circ} \mathbf{C}\right)$ & $\begin{array}{c}\text { Ethane Conversion } \\
(\mathbf{w t .} \%)\end{array}$ & $\begin{array}{c}\text { Ethylene Selectivity } \\
(\mathbf{\%})\end{array}$ & Reference \\
\hline $\mathrm{Cr}-\mathrm{Ce}$ & 700 & 55 & 96 & {$[57]$} \\
$\mathrm{Cr}-\mathrm{Zr}$ & 700 & 65 & 87 & {$[58]$} \\
$\mathrm{Fe}-\mathrm{Cr}$ & 650 & 54 & 93 & {$[59]$} \\
$\mathrm{Cr}_{2} \mathrm{O}_{3}$ & 650 & 27 & 87 & {$[60]$} \\
\hline
\end{tabular}


Table 4. Cont.

\begin{tabular}{ccccc}
\hline Membrane Type & Temperature $\left({ }^{\circ} \mathbf{C}\right)$ & $\begin{array}{c}\text { Ethane Conversion } \\
\text { (wt.\%) }\end{array}$ & $\begin{array}{c}\text { Ethylene Selectivity } \\
(\mathbf{\%})\end{array}$ & Reference \\
\hline $\mathrm{Cr}-\mathrm{Si}$ & 650 & 62 & 81 & {$[61]$} \\
$\mathrm{Ga}-\mathrm{Si}$ & 650 & 25 & 92 & {$[62]$} \\
$\mathrm{Ga}-\mathrm{Si}-\mathrm{Ti}$ & 650 & 47 & 57 & {$[63]$} \\
$\mathrm{Ga}-\mathrm{Ti}$ & 700 & 38 & 92 & {$[53]$} \\
$\mathrm{Co}-\mathrm{Ba}$ & 650 & 48 & 85 & {$[64]$} \\
$\mathrm{Co}-\mathrm{Si}$ & 700 & 46 & 60 & {$[65]$} \\
$\mathrm{Mo}_{2} \mathrm{C}$ & 600 & 2 & {$[66]$} \\
\hline
\end{tabular}

\section{The Membrane Oxidative Dehydrogenation Technology}

Membrane ODH is able to solve the air separation and process safety problems associated with the combined supply of feed and $\mathrm{O}_{2}$. Instead of a RedOx catalyst, a dense membrane with mixed ionic - electronic conductivity (MIEC), is used. MIEC is integrated with the catalysts to allow oxygen permeation and air separation [67]. The efficiency of carrying out the ODH process in a multitube membrane reactor is pretty high [68]. It is assumed that the inert membrane tubes are filled with catalyst particles, and oxygen is metered from the side of the housing through the membrane into the tubes, as shown in Figure 2 .
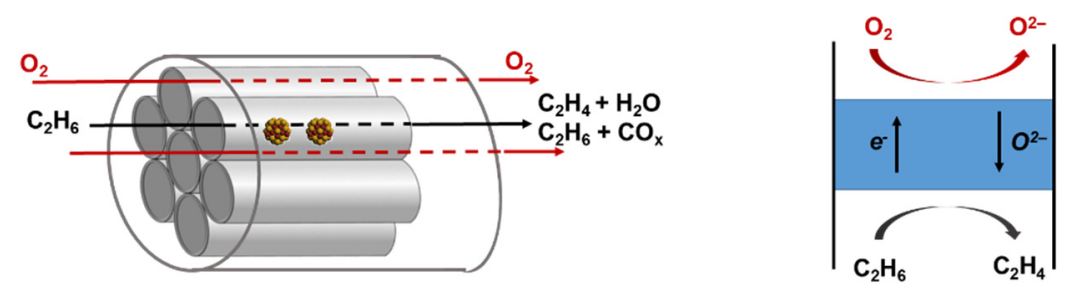

Figure 2. Scheme of a membrane reactor for oxidative dehydrogenation of ethane.

The configuration of such a reactor leads to a softer temperature profile, a decrease in the partial pressure, which increases the selectivity to ethylene. Under certain operating conditions, an undesirable oxygen build-up phenomenon can occur within the catalyst bed, which can be minimized by carefully adjusting the process conditions.

The dense mixed ionic electronic conductor membrane divides the reactor into two zones: a reaction zone and an oxygen-enriched zone. The driving force is the oxygen partial pressure gradient across the membrane. The application of a membrane reactor has the following advantages: (1) air separation takes place on site; (2) there is a possibility of increasing the yield and selectivity above the thermodynamic limits; (3) this method can be more efficient and relatively safe to operate.

It should be noted that cyclic oxidation and membrane methods can be potentially interesting, in addition to traditional catalytic approaches [69]. MIEC membranes showed excellent permeability at elevated temperatures and with a high separation selectivity (up to $100 \%$ ). This technology is highly attractive in terms of selective ODH process due to the fact that separation and reaction are integrated in the same unit. Table 5 summarizes the process conditions and catalytic performances of membrane type technology. 
Table 5. Catalytic performance of the different membrane-based ethane ODH.

\begin{tabular}{|c|c|c|c|c|}
\hline Membrane Type & Temperature $\left({ }^{\circ} \mathrm{C}\right)$ & $\begin{array}{l}\text { Ethane Conversion } \\
\text { (wt. } \%)\end{array}$ & $\begin{array}{c}\text { Ethylene Selectivity } \\
(\%)\end{array}$ & Reference \\
\hline Bi-Y-Sm & 875 & 75 & 75 & [70] \\
\hline $\mathrm{Pt}-\mathrm{Al}_{2} \mathrm{O}_{3}$ & 600 & 46 & 96 & [71] \\
\hline Li-Mg-Sm & 600 & 95 & 53 & [72] \\
\hline $\mathrm{Ba}-\mathrm{Sr}-\mathrm{Co}-\mathrm{Fe}$ & 850 & 90 & 65 & [43] \\
\hline Ba-Sr-Co-Fe-Pd & 850 & 90 & 60 & [69] \\
\hline Ba-Co-Fe-Zr & 850 & 83 & 25 & [73] \\
\hline Ba-Sr-Co-Fe & 850 & 90 & 90 & [74] \\
\hline Ba-Fe-Mg-Ce-Gd & 750 & 85 & 65 & [75] \\
\hline
\end{tabular}

\section{Chemical Looping Oxidative Dehydrogenation}

Conventional ODH of ethane requires oxygen gas, which can lead to increased process costs (as air separation is required) and safety concerns (due to the simultaneous presence of ethane and $\mathrm{O}_{2}$ ). To eliminate the potential problems associated with co-feeding feedstock and $\mathrm{O}_{2}$, the $\mathrm{ODH}$-cyclic oxidation method uses oxygen from the crystal lattice of a metal oxide mediator, also known as a RedOx (reduction-oxidation) catalyst, to convert ethane $[4,5]$. The catalyst carries oxygen from the regenerator to the reactor and aids in the conversion of ethane to ethylene. There is no direct contact between the feedstock and the gaseous oxidizer. The oxidizing agent in this process is the lattice oxygen contained in the catalyst. The catalyst in the reactor interacts with the feedstock for the required reaction time, after which it is reoxidized in the regenerator to restore the lattice oxygen content [76]. The technological solution to this problem is achieved through the implementation of the process with the reaction of the oxidative conversion of ethane to ethylene and the regeneration of the catalyst in two separate apparatuses with separate feed of the feedstock and the oxidant (Figure 3) [77,78]. This technique provides a technological development advantage due to the continuity of the corresponding reactions in each individual apparatus, ease of control and flexibility of the process, excluding the ingress of ballast nitrogen into the reaction products. It should be noted that by-product hydrogen $\mathrm{H}_{2}$ limits the conversion of ethane, whereas the selective oxidation of ethane occurs the formation of $\mathrm{H}_{2} \mathrm{O}$ leading to much higher single pass yield of ethylene. The increase in the yield of ethylene leads to a lowered molar flow rate of non-condensable gaseous products from the reaction, which makes it a much more energy efficient process [79].

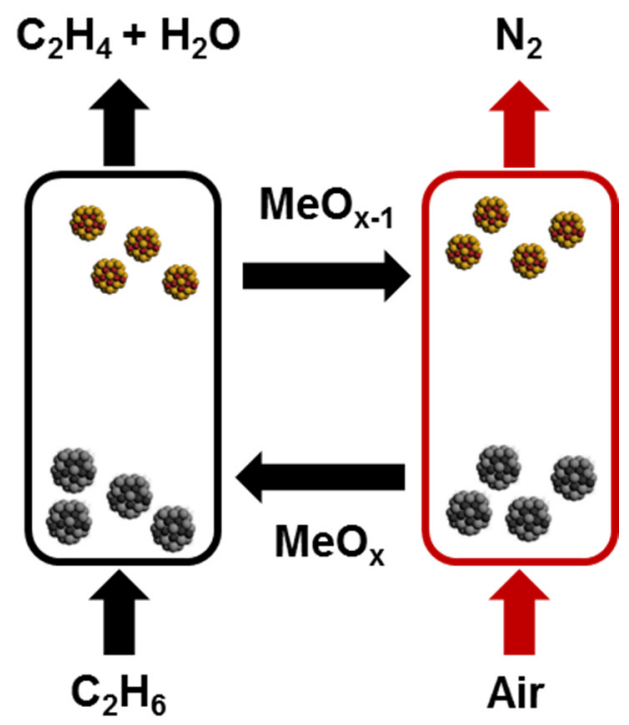

Figure 3. Schematic of the chemical looping process. 
In cyclic oxidation schemes, the redox catalyst is in a state of dynamic change between the ethane $\mathrm{ODH}$ and air regeneration stages, due to the concomitant consumption and regeneration of crystal lattice oxygen. As a result, the catalytic properties of a redox catalyst are also a function of time, as indicated by some studies on cyclic oxidation [80]. The general trend is the following: surface oxygen weakly bound to the catalyst surface exhibits lower selectivity, which leads to more COx formation at the beginning of the ODH stage, and strongly bound oxygen and/or belonging to the crystal lattice is more selective, which leads to an increase in selectivity, but decrease in conversion over time. Thus, in order to achieve the best ethylene yield, the optimal residence time should be chosen in the ethane $\mathrm{ODH}$ stage and in the air regeneration stage.

Chemical looping ODH (CL-ODH) of ethane process requires an oxidizing catalyst, an oxidizing catalyst gives away its lattice oxygen under an air/oxygen flow. After that, the reduced catalyst is exposed to an oxidizing flow renewing its lattice oxygen. If the catalysts is synthesized properly, they can facilitate the high selectivity towards valued products with minimal separation requirements. Those catalysts are typically porous materials with high surface area in order to reduce diffusion limitations [81-85]. Catalyst particles usually contain metal oxides with the following features: the presence of oxygen vacancies and developed pore system. They have to possess long-term catalytic, mechanic, and thermal stability, they also should have favorable thermodynamics, and last but not least, they should have a low cost $[4,6]$. Oxygen carriers should be reducible in order to be able to perform the RedOx process. The representative examples are $\mathrm{Fe}_{2} \mathrm{O}_{3}$ and $\mathrm{MoO}_{3}[84,86]$. These oxides are usually promoted by some additives in order to develop high surface area and increase catalyst activity. An optimal oxygen carrier possesses a mobile lattice oxygen atoms in order to accelerate the oxidizing reactions providing required kinetics. There are several structures that fully meet these requirements: fluorite, perovskite, and rocksalt [76,87-89]. Fluorite structures like cerium oxide have oxygen anion Frenkel defects. It forms when oxygen leaves its place in the lattice, creating a vacancy, and becomes an interstitial site. Therefore, it can form solid solutions with oxygen vacancies, providing required activity in RedOx processes. The perovskite structure has a common formula of $\mathrm{ABO}_{3}$, where $\mathrm{A}$ is a lanthanide ion and/or alkaline earth metal, $\mathrm{B}$ is a transition metal cation. Just like fluorite, a perovskite structure contains a high concentration of oxide vacancies. Therefore, they exhibit high activity in the oxidation processes.

Transition metal oxide such as vanadium and molybdenum have been reported as effective catalysts for $\mathrm{ODH}$ of ethane. For example, the catalyst type of $\mathrm{MoO}_{3}-\mathrm{Fe}_{2} \mathrm{O}_{3}$ showed high ethylene selectivity (57-62\%) at $600{ }^{\circ} \mathrm{C}$ [86]. Molybdenum and manganesecontaining materials possessed high-temperature stability, low cost, and of course high effectiveness in the oxidative reaction of light hydrocarbons [90,91]. The manganese oxides catalysts (MnOx) based on silica and $\mathrm{MnO}$ on $\mathrm{MgO}$ demonstrated low ethylene selectivity; however, the promotion with sodium and sodium tungstate allowed to obtain effective oxygen donation capacity, selectivity, and redox stability. Mixing manganese oxide along with silica oxide allowed to obtain manganese silicate, which proved to be an effective strategy to achieve significantly higher ethylene yields than either $\mathrm{MnOx} / \mathrm{SiO}_{2}$ or thermal cracking. Gong et al. developed the bifunctional molybdenum-vanadium mixed oxides for highly effective oxidation of propane at relatively low temperatures (up to $500{ }^{\circ} \mathrm{C}$ ) through the two-step chemical looping oxidative dehydrogenation approach [84]. The yield of propylene using $\mathrm{Mo}-\mathrm{V}-\mathrm{O}$ oxides greatly exceeds that of previously reported ODH catalysts [5]. The high conversion remained after 100 dehydrogenation-regeneration cycles. The list of CL-ODH is summarized in Table 6. 
Table 6. Catalytic performance of the different CL-ODH.

\begin{tabular}{ccccc}
\hline Catalyst Type & Temperature $\left({ }^{\circ} \mathbf{C}\right)$ & Conversion (wt. \%) & Selectivity (\%) & Reference \\
\hline Mo-V $/ \mathrm{Al}_{2} \mathrm{O}_{3}$ & 500 & 36 & 89 & {$[84]$} \\
$\mathrm{Mg}-\mathrm{Mn}-\mathrm{O}-\mathrm{Na}$ & 850 & 92 & 12 & {$[91]$} \\
$\mathrm{Mg}-\mathrm{Mn}-\mathrm{O}-\mathrm{Na}-\mathrm{P}$ & 850 & 87 & 51 & {$[91]$} \\
$\mathrm{Mg}-\mathrm{Mn}-\mathrm{O}-\mathrm{Na}-\mathrm{W}$ & 850 & 78 & 59 & {$[91]$} \\
$\mathrm{Mn}-\mathrm{Si}-\mathrm{O}$ & 850 & 81 & 87 & {$[90]$} \\
$\mathrm{Mn}-\mathrm{Si}-\mathrm{O}-\mathrm{W}$ & 850 & 67 & 43 & {$[90]$} \\
$\mathrm{Fe}-\mathrm{Mn}-\mathrm{O}$ & 850 & 79 & 42 & {$[92]$} \\
$\mathrm{Fe}-\mathrm{O}$ & 600 & 33 & 57 & {$[86]$} \\
$\mathrm{Mo}-\mathrm{Fe}-\mathrm{O}$ & 600 & 60 & 86 & {$[86]$} \\
$\mathrm{La}-\mathrm{Sr}-\mathrm{Fe}-\mathrm{O}-\mathrm{Na}$ & 700 & 85 & 18 & {$[89]$} \\
$\mathrm{Mn}-\mathrm{Mg}-\mathrm{O}$ & 850 & & {$[76]$} \\
\hline
\end{tabular}

A new approach similar to CL-ODH technology was proposed for oxidative dehydrogenation of ethane, which implies carrying out the process in two separate apparatuses-a reactor and a regenerator, between which a microspherical catalyst containing active lattice oxygen is continuously circulating [5]. A close working technology design is the catalytic cracking of vacuum gas oil in a moving bed of a microspherical zeolite-containing catalyst $[6,46]$.

Experiments on the ODH of ethane with a circulating microspherical solid contact were carried out in a pilot setup (Figure 4) with a total catalyst load of $2 \mathrm{~L}$. The catalyst had the form of a mixed oxide of composition Mo- $\mathrm{V}-\mathrm{O}$ deposited in an amount of $10 \mathrm{wt} . \%$ on the microspherical (average fraction $70 \mu \mathrm{m}) \gamma-\mathrm{Al}_{2} \mathrm{O}_{3}$. The setup includes a reactor unit (dehydrogenation reactor), a regeneration unit (oxidation reactor), and a control unit. The feed (ethane) enters the lower part of the dehydrogenation reactor 1 , where it contacts with the catalyst, which comes from the transport line 2 of the oxidation reactor. The reaction products, together with the catalyst, enter the separator of the dehydrogenation reactor 3 , where they are separated, then into the dust separator 4 , where the catalyst dust is deposited and then escapes into the atmosphere. The reduced catalyst enters the transport line 5 , then is picked up by the nitrogen flow and rises through the pneumatic lifter 6 into the oxidation reactor 7 , where it is oxidized by atmospheric oxygen. The oxidation of the catalyst takes place in a fluidized bed, which is supported by a stream of air. Then, the catalyst flows through the transport line 2 to the dehydrogenation reactor. The oxidation products, containing mainly nitrogen, are separated from the catalyst in the separator of the oxidation reactor 8 and, after cooling in the water cooler 9 , go further into the atmosphere. The preparation of Mo catalysts is characterized by simplicity and complete reproducibility of their properties. The experiments were carried out at a temperature of $565-635^{\circ} \mathrm{C}$, the mass feed rate was $1.6-3.6 \mathrm{~h}^{-1}$, the duration of each experiment was $240 \mathrm{~min}$, the regeneration temperature was $650^{\circ} \mathrm{C}$, oxidizing agent: raw material mass ratio was 0.45 .

Table 7 shows the comparative data on the composition of ethane conversion products in industrial reactors of the EP-300 unit, autothermal ethane pyrolysis using air as an oxidant, and oxidative conversion of ethane CL-ODH. The composition of initial ethane fraction: methane- $-17 \mathrm{wt} . \%$, ethane- $99.83 \mathrm{wt} . \%$. As can be seen from the presented data, the ethylene selectivity for the developed technology significantly exceeds the level of the thermal pyrolysis technology [18]. Our calculations showed that the specific capital costs (ethylene productivity of 300 thousand tons/year) for the developed technology for the oxidative conversion of ethane to ethylene with separate feed and an oxidizer in comparison with thermal pyrolysis of ethane are 630 and $1035 \mathrm{USD} / \mathrm{t}$ of ethylene, respectively. The separation of feed and oxidizer provides high energy efficiency-there are practically no costs for heating raw materials and air; heat transfer is carried out by a circulating microspherical catalyst-oxidant-heat carrier; the heat balance in the system is provided by the energy released during exothermic reactions-oxidative dehydrogenation of ethane in the reactor and oxidation of metals with oxygen. 


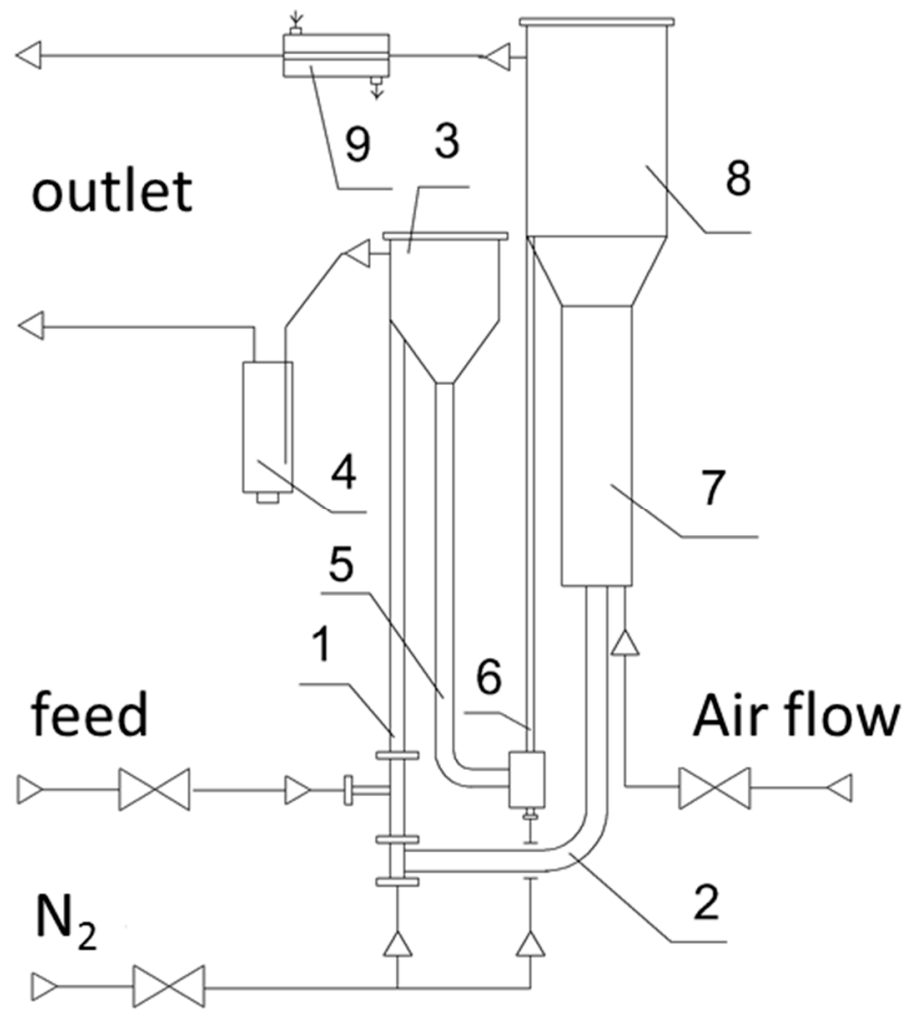

Figure 4. Schematic diagram of a pilot setup with a circulating oxygen carrier for ODH in a continuous mode.

Table 7. Selectivity towards light products of different technology compared to CL-ODH process (\%).

\begin{tabular}{cccc}
\hline Product & Pyrolysis in EP-300 Furnaces & Autothermal Pyrolysis & CL-ODH \\
\hline $\mathrm{CH}_{4}$ & 5.9 & 5.5 & 2.8 \\
$\mathrm{C}_{2} \mathrm{H}_{2}$ & 0.4 & 0.2 & 0 \\
$\mathrm{C}_{2} \mathrm{H}_{4}$ & 77.9 & 79.7 & 89.2 \\
$\Sigma \mathrm{C}_{3} \mathrm{H}_{6}$ & 2.9 & 4.3 & 0.2 \\
$\sum \mathrm{C}_{4} \mathrm{H}_{8}$ & 4.4 & 0.5 & 0.1 \\
$\mathrm{C}_{3} \mathrm{H}_{4}$ & 0.7 & 0 & 0 \\
$\mathrm{C}_{5+}$ & 7.5 & 0 & 0 \\
$\mathrm{C}_{\text {ox }}$ & 0.3 & 9.8 & 7.7 \\
\hline
\end{tabular}

The high selectivity towards ethylene (up to $90 \%$ ) provides the low consumption of ethane per ethylene, making the process much more efficient compared to pyrolysis and cracking. By combining different reduction and oxidation reactions, we can envisage a variety of chemical looping processes that yield clean and efficient power, fuels, and other chemicals.

\section{New Trends in the Ethane Conversion Process}

Photocatalysis is an alternative approach using clean solar energy to activate the ethane molecule and $\mathrm{CO}_{2}$ under mild conditions [93]. As was mentioned earlier, one of the promising processes for producing ethylene, is the $\mathrm{ODH}$ of ethane in the presence of $\mathrm{CO}_{2}$ as a soft oxidant [50]. Since ODH with $\mathrm{CO}_{2}$ takes place at high temperatures, photo-oxidation of ethane with $\mathrm{CO}_{2}$ can be a possible way to improve the process [93-95]. Zhang and co-workers demonstrated that the $\mathrm{Pd}$ on $\mathrm{TiO}_{2}$ materials are prospective catalysts for the photocatalytic $\mathrm{ODH}$ with $\mathrm{CO}_{2}$ at room temperature [94]. They showed that $\mathrm{CO}_{2}$ significantly improved products, leading to the production rates of 230.5 and $282.6 \mu \mathrm{mol} / \mathrm{g} \cdot \mathrm{cat} \cdot \mathrm{h}$ for $\mathrm{C}_{2} \mathrm{H}_{4}$ and syngas, respectively. The studies in photocatalytic conversion of ethane are 
still in its preliminary stage and very few of them are focused on ethylene production. The main reason is due to very low selectivity towards desired products.

In contrast to catalytic ODH, electrochemical methods have the potential to achieve lower thermal energy requirement and higher efficiency [96-100]. For example, solid RedOx membrane reactors have become a potentially attractive alternative due to the ability to operate at elevated temperatures. The advantages include the selectivity towards ethylene no longer depends on the thermodynamic equilibrium. Wang and co-workers reported an oxygen fuel cell with Ba-Ce-Y-O as an electrolyte support and platinum as both anode and cathode catalysts [96]. Two steps have been described: production of hydrogen due to dehydrogenation of ethane at $650{ }^{\circ} \mathrm{C}$ and direct conversion of ethane at $700{ }^{\circ} \mathrm{C}$. It was also mentioned that the hydrogen generated in this process was pure. A $34 \%$ ethane conversion with $96 \%$ ethylene selectivity was achieved in this $\mathrm{Pt} / \mathrm{BCY} 15 / \mathrm{Pt}$ PEMR system at $700{ }^{\circ} \mathrm{C}$. Ding et al. reported a non-oxidative process to produce ethylene and hydrogen [97]. The study showed a production of ethylene from ethane through via electrochemical dehydrogenation process at $400{ }^{\circ} \mathrm{C}$ using Ba-Zr-Ce-Y-Yb-O electrolyte, $\mathrm{Pr}-\mathrm{Ba}-\mathrm{Sr}-\mathrm{Co}-\mathrm{Fe}-\mathrm{O}$ anode, and Ni-Ba-Zr-Ce-Y-Yb cathode.

Given that the electrochemical system is more complicated than that of conventional thermochemical processes, many problems are still unsolved. There is a limitation of highly selective electrocatalysts due to the instability of materials in long-term processes. Therefore, scale-up of the process with incorporation of electrocatalysts could bring new problems in ethylene production.

\section{Conclusions}

Recent developments in technology for EDH and ODH have been described from the perspective of catalysts activity and selectivity towards ethylene. The ODH and EDH catalysts have been intensively investigated. It should be noted that each method offers unique advantages facing challenges. Membrane- and chemical-looping ODH routes possess the potential to enhance ethylene production due to their potential to integrate multiple operations in a compact system. There has been a recent push in design of the chemical looping technology. Chemical looping exemplifies the vanguard of materials science and mechanical properties, kinetic study, and flow stability. Although great efforts have been made in the development of oxygen carriers to optimize the ODH processes and chemical looping process in particularly, the reported materials are still not satisfied in the economic aspects. There should be more funding in the technological problems. With the development of pilot-scale studies, including the one we described, there can be no doubt that chemical looping technology has the potential to be commercially deployable in the near future for the highly selective dehydrogenation of ethane.

Author Contributions: Writing-original draft preparation and investigation, D.F.; data curation, I.G.; funding acquisition, A.M.; conceptualization, writing-review and editing, E.N. All authors have read and agreed to the published version of the manuscript.

Funding: This research was done as part of TIPS RAS State Plan.

Conflicts of Interest: The authors declare no conflict of interest.

\section{References}

1. Saito, H.; Sekine, Y. Catalytic conversion of ethane to valuable products through non-oxidative dehydrogenation and dehydroaromatization. RSC Adv. 2020, 10, 21427-21453. [CrossRef]

2. Ren, T.; Patel, M.; Blok, K. Olefins from conventional and heavy feedstocks: Energy use in steam cracking and alternative processes. Energy 2006, 31, 425-451. [CrossRef]

3. Amghizar, I.; Vandewalle, L.A.; Van Geem, K.M.; Marin, G.B. New Trends in Olefin Production. Engineering 2017, 3, 171-178. [CrossRef]

4. Zhu, X.; Imtiaz, Q.; Donat, F.; Müller, C.R.; Li, F. Chemical looping beyond combustion-a perspective. Energy Environ. Sci. 2020, 13, 772-804. [CrossRef]

5. Li, D.; Xu, R.; Li, X.; Li, Z.; Zhu, X.; Li, K. Chemical Looping Conversion of Gaseous and Liquid Fuels for Chemical Production: A Review. Energy Fuels 2020, 34, 5381-5413. [CrossRef] 
6. Gao, Y.; Neal, L.; Ding, D.; Wu, W.; Baroi, C.; Gaffney, A.M.; Li, F. Recent Advances in Intensified Ethylene Production-A Review. ACS Catal. 2019, 9, 8592-8621. [CrossRef]

7. Sattler, J.J.H.B.; Ruiz-Martinez, J.; Santillan-Jimenez, E.; Weckhuysen, B.M. Catalytic dehydrogenation of light alkanes on metals and metal oxides. Chem. Rev. 2014, 114, 10613-10653. [CrossRef] [PubMed]

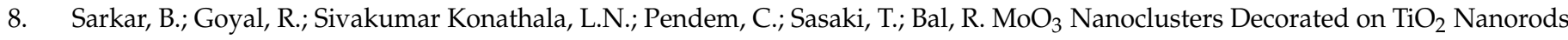
for Oxidative dehydrogenation of ethane to ethylene. Appl. Catal. B Environ. 2017, 217, 637-649. [CrossRef]

9. Gong, S.; Shao, C.; Zhu, L. Energy efficiency evaluation in ethylene production process with respect to operation classification. Energy 2017, 118, 1370-1379. [CrossRef]

10. Zhao, Z.; Chong, K.; Jiang, J.; Wilson, K.; Zhang, X.; Wang, F. Low-carbon roadmap of chemical production: A case study of ethylene in China. Renew. Sustain. Energy Rev. 2018, 97, 580-591. [CrossRef]

11. Chen, J.M.; Yu, B.; Wei, Y.M. Energy technology roadmap for ethylene industry in China. Appl. Energy 2018, 224, 160-174. [CrossRef]

12. Propylene-Study: Market, Analysis, Trends ICeresana. Available online: https://www.ceresana.com/en/market-studies/ chemicals/propylene/ (accessed on 30 May 2021).

13. Ethylene Uses and Market Data. Available online: http:/ /www.icis.com/Articles/2007/11/05/9075777/ethylene-uses-andmarket-data.html (accessed on 30 May 2021).

14. Al-Douri, A.; Sengupta, D.; El-Halwagi, M.M. Shale gas monetization-A review of downstream processing to chemicals and fuels. J. Nat. Gas Sci. Eng. 2017, 45, 436-455. [CrossRef]

15. Yang, M.; You, F. Comparative Techno-Economic and Environmental Analysis of Ethylene and Propylene Manufacturing from Wet Shale Gas and Naphtha. Ind. Eng. Chem. Res. 2017, 56, 4038-4051. [CrossRef]

16. He, C.; You, F. Shale gas processing integrated with ethylene production: Novel process designs, exergy analysis, and technoeconomic analysis. Ind. Eng. Chem. Res. 2014, 53, 11442-11459. [CrossRef]

17. America's New Energy Future: The Unconventional Oil \& Gas Revolution and the US Economy. Available online: http: //www.ihs.com/info/ecc/a/americas-new-energy-future-report-vol-3.aspx (accessed on 30 May 2021).

18. Gerzeliev, I.M.; Fairuzov, D.K.; Gerzelieva, Z.I.; Maksimov, A.L. Production of Ethylene from Ethane Fraction by a Method Alternative to Steam Cracking. Russ. J. Appl. Chem. 2019, 92, 1549-1557. [CrossRef]

19. Gaffney, A.M.; Mason, O.M. Ethylene production via Oxidative Dehydrogenation of Ethane using M1 catalyst. Catal. Today 2017, 285, 159-165. [CrossRef]

20. Muñoz Gandarillas, A.E.; Van Geem, K.M.; Reyniers, M.F.; Marin, G.B. Influence of the reactor material composition on coke formation during ethane steam cracking. Ind. Eng. Chem. Res. 2014, 53, 6358-6371. [CrossRef]

21. Van Goethem, M.W.M.; Barendregt, S.; Grievink, J.; Moulijn, J.A.; Verheijen, P.J.T. Ideal chemical conversion concept for the industrial production of ethene from hydrocarbons. Ind. Eng. Chem. Res. 2007, 46, 4045-4062. [CrossRef]

22. van Goethem, M.W.M.; Barendregt, S.; Grievink, J.; Verheijen, P.J.T.; Dente, M.; Ranzi, E. A kinetic modelling study of ethane cracking for optimal ethylene yield. Chem. Eng. Res. Des. 2013, 91, 1106-1110. [CrossRef]

23. Galvita, V.; Siddiqi, G.; Sun, P.; Bell, A.T. Ethane dehydrogenation on Pt/Mg(Al)O and PtSn/Mg(Al)O catalysts. J. Catal. 2010, 271, 209-219. [CrossRef]

24. Wegener, E.C.; Wu, Z.; Tseng, H.T.; Gallagher, J.R.; Ren, Y.; Diaz, R.E.; Ribeiro, F.H.; Miller, J.T. Structure and reactivity of Pt-In intermetallic alloy nanoparticles: Highly selective catalysts for ethane dehydrogenation. Catal. Today 2018, 299, 146-153. [CrossRef]

25. Peng, G.; Gerceker, D.; Kumbhalkar, M.; Dumesic, J.A.; Mavrikakis, M. Ethane dehydrogenation on pristine and AlO: X decorated Pt stepped surfaces. Catal. Sci. Technol. 2018, 8, 2159-2174. [CrossRef]

26. Wu, J.; Peng, Z.; Bell, A.T. Effects of composition and metal particle size on ethane dehydrogenation over PtxSn100-x/Mg(Al)O (70 $\leq \mathrm{x} \leq$ 100). J. Catal. 2014, 311, 161-168. [CrossRef]

27. Siddiqi, G.; Sun, P.; Galvita, V.; Bell, A.T. Catalyst performance of novel Pt/Mg(Ga)(Al)O catalysts for alkane dehydrogenation. J. Catal. 2010, 274, 200-206. [CrossRef]

28. Xie, Q.; Lei, T.; Miao, C.; Hua, W.; Yue, Y.; Gao, Z. Au/TiO 2 for Ethane Dehydrogenation: Effect of Silica Doping. Catal. Letters 2020, 150, 2013-2020. [CrossRef]

29. Monoue, R.; Galiasso, R.; Giannetto, G. Transformation of LPG into Aromatic Hydrocarbons and Hydrogen over Zeolite Catalysts. Catal. Rev. 1994, 36, 271-304. [CrossRef]

30. Bhan, A.; Delgass, W.N. Propane aromatization over HZSM-5 and Ga/HZSM-5 catalysts. Catal. Rev. Sci. Eng. 2008, 50, 19-151. [CrossRef]

31. Rao, T.V.M.; Zahidi, E.M.; Sayari, A. Ethane dehydrogenation over pore-expanded mesoporous silica-supported chromium oxide: 2. Catalytic properties and nature of active sites. J. Mol. Catal. A Chem. 2009, 301, 159-165. [CrossRef]

32. Yang, X.; Wei, T.; Chi, B.; Pu, J.; Li, J. Lanthanum manganite-based perovskite as a catalyst for co-production of ethylene and hydrogen by ethane dehydrogenation. J. Catal. 2019, 377, 629-637. [CrossRef]

33. Toko, K.; Ito, K.; Saito, H.; Hosono, Y.; Murakami, K.; Misaki, S.; Higo, T.; Ogo, S.; Tsuneki, H.; Maeda, S.; et al. Catalytic Dehydrogenation of Ethane over Doped Perovskite via the Mars-van Krevelen Mechanism. J. Phys. Chem. C 2020, 124, 10462-10469. [CrossRef] 
34. Saito, H.; Seki, H.; Hosono, Y.; Higo, T.; Seo, J.G.; Maeda, S.; Hashimoto, K.; Ogo, S.; Sekine, Y. Dehydrogenation of Ethane via the Mars-van Krevelen Mechanism over $\mathrm{La}_{0.8} \mathrm{Ba}_{0.2} \mathrm{MnO}_{3-\delta}$ Perovskites under Anaerobic Conditions. J. Phys. Chem. C 2019, 123, 26272-26281. [CrossRef]

35. Nakagawa, K.; Kajita, C.; Ide, Y.; Okamura, M.; Kato, S.; Kasuya, H.; Ikenaga, N.O.; Kobayashiand, T.; Suzuki, T. Promoting effect of carbon dioxide on the dehydrogenation and aromatization of ethane over gallium-loaded catalysts. Catal. Lett. 2000, 64, 215-221. [CrossRef]

36. Wang, L.C.; Zhang, Y.; Xu, J.; Diao, W.; Karakalos, S.; Liu, B.; Song, X.; Wu, W.; He, T.; Ding, D. Non-oxidative dehydrogenation of ethane to ethylene over ZSM-5 zeolite supported iron catalysts. Appl. Catal. B Environ. 2019, 256, 117816. [CrossRef]

37. Olsbye, U.; Virnovskaia, A.; Prytz, O.; Tinnemans, S.J.; Weckhuysen, B.M. Mechanistic insight in the ethane dehydrogenation reaction over $\mathrm{Cr} / \mathrm{Al}_{2} \mathrm{O}_{3}$ catalysts. Catal. Lett. 2005, 103, 143-148. [CrossRef]

38. Yokoyama, C.; Bharadwaj, S.S.; Schmidt, L.D. Platinum-Tin and Platinum-Copper Catalysts for Autothermal Oxidative Dehydrogenation of Ethane to Ethylene. 1996, 38, 181-188.

39. Donsì, F.; Williams, K.A.; Schmidt, L.D. A multistep surface mechanism for ethane oxidative dehydrogenation on Pt- And $\mathrm{Pt} / \mathrm{Sn}$-coated monoliths. Ind. Eng. Chem. Res. 2005, 44, 3453-3470. [CrossRef]

40. Skoufa, Z.; Heracleous, E.; Lemonidou, A.A. Investigation of engineering aspects in ethane ODH over highly selective Ni0.85Nb0.15Ox catalyst. Chem. Eng. Sci. 2012, 84, 48-56. [CrossRef]

41. Solsona, B.; Dejoz, A.; Garcia, T.; Concepción, P.; Nieto, J.M.L.; Vázquez, M.I.; Navarro, M.T. Molybdenum-vanadium supported on mesoporous alumina catalysts for the oxidative dehydrogenation of ethane. Catal. Today 2006, 117, 228-233. [CrossRef]

42. Cavani, F.; Ballarini, N.; Cericola, A. Oxidative dehydrogenation of ethane and propane: How far from commercial implementation? Catal. Today 2007, 127, 113-131. [CrossRef]

43. Wang, H.; Cong, Y.; Yang, W. Continuous oxygen ion transfer medium as a catalyst for high selective oxidative dehydrogenation of ethane. Catal. Lett. 2002, 84, 101-106. [CrossRef]

44. Shi, L.; Yan, B.; Shao, D.; Jiang, F.; Wang, D.; Lu, A.H. Selective oxidative dehydrogenation of ethane to ethylene over a hydroxylated boron nitride catalyst. Cuihua Xuebao/Chin. J. Catal. 2017, 38, 389-395. [CrossRef]

45. Baroi, C.; Gaffney, A.M.; Fushimi, R. Process economics and safety considerations for the oxidative dehydrogenation of ethane using the M1 catalyst. Catal. Today 2017, 298, 138-144. [CrossRef]

46. Nakamura, K.I.; Miyake, T.; Konishi, T.; Suzuki, T. Oxidative dehydrogenation of ethane to ethylene over NiO loaded on high surface area MgO. J. Mol. Catal. A Chem. 2006, 260, 144-151. [CrossRef]

47. Frank, B.; Morassutto, M.; Schomäcker, R.; Schlögl, R.; Su, D.S. Oxidative dehydrogenation of ethane over multiwalled carbon nanotubes. ChemCatChem 2010, 2, 644-648. [CrossRef]

48. Zhu, H.; Dong, H.; Laveille, P.; Saih, Y.; Caps, V.; Basset, J.M. Metal oxides modified NiO catalysts for oxidative dehydrogenation of ethane to ethylene. Catal. Today 2014, 228, 58-64. [CrossRef]

49. Gärtner, C.A.; Van Veen, A.C.; Lercher, J.A. Oxidative dehydrogenation of ethane on dynamically rearranging supported chloride catalysts. J. Am. Chem. Soc. 2014, 136, 12691-12701. [CrossRef]

50. Maffia, G.J.; Gaffney, A.M.; Mason, O.M. Techno-Economic Analysis of Oxidative Dehydrogenation Options. Top. Catal. 2016, 59, 1573-1579. [CrossRef]

51. Wang, S.; Murata, K.; Hayakawa, T.; Hamakawa, S.; Suzuki, K. Oxidative dehydrogenation of ethane by carbon dioxide over sulfate-modified $\mathrm{Cr}_{2} \mathrm{O}_{3} / \mathrm{SiO}_{2}$ catalysts. Catal. Lett. 1999, 63, 59-64. [CrossRef]

52. Shi, X.; Ji, S.; Li, C. Oxidative dehydrogenation of ethane with $\mathrm{CO}_{2}$ over novel $\mathrm{Cr} / \mathrm{SBA}-15 / \mathrm{Al}_{2} \mathrm{O}_{3} / \mathrm{FeCrAl}$ monolithic catalysts. Energy Fuels 2008, 22, 3631-3638. [CrossRef]

53. Koirala, R.; Buechel, R.; Krumeich, F.; Pratsinis, S.E.; Baiker, A. Oxidative dehydrogenation of ethane with $\mathrm{CO}_{2}$ over flame-made Ga-loaded $\mathrm{TiO}_{2}$. ACS Catal. 2015, 5, 690-702. [CrossRef]

54. Yabe, T.; Sekine, Y. Methane conversion using carbon dioxide as an oxidizing agent: A review. Fuel Process. Technol. 2018, 181, 187-198. [CrossRef]

55. Wang, S.; Zhu, Z.H. Catalytic conversion of alkanes to olefins by carbon dioxide oxidative dehydrogenation-A review. Energy Fuels 2004, 18, 1126-1139. [CrossRef]

56. Artz, J.; Müller, T.E.; Thenert, K.; Kleinekorte, J.; Meys, R.; Sternberg, A.; Bardow, A.; Leitner, W. Sustainable Conversion of Carbon Dioxide: An Integrated Review of Catalysis and Life Cycle Assessment. Chem. Rev. 2018, 118, 434-504. [CrossRef]

57. Shi, X.; Ji, S.; Wang, K. Oxidative dehydrogenation of ethane to ethylene with carbon dioxide over Cr-Ce/SBA-15 catalysts. Catal. Lett. 2008, 125, 331-339. [CrossRef]

58. Rahmani, F.; Haghighi, M.; Mohammadkhani, B. Enhanced dispersion of $\mathrm{Cr}$ nanoparticles over nanostructured $\mathrm{ZrO}_{2}$-doped ZSM-5 used in $\mathrm{CO}_{2}$-oxydehydrogenation of ethane. Microporous Mesoporous Mater. 2017, 242, 34-49. [CrossRef]

59. Deng, S.; Li, H.; Li, S.; Zhang, Y. Activity and characterization of modified $\mathrm{Cr}_{2} \mathrm{O}_{3} / \mathrm{ZrO}_{2}$ nano-composite catalysts for oxidative dehydrogenation of ethane to ethylene with $\mathrm{CO}_{2}$. J. Mol. Catal. A Chem. 2007, 268, 169-175. [CrossRef]

60. Nakagawa, K.; Kajita, C.; Ikenaga, N.O.; Suzuki, T.; Kobayashi, T.; Nishitani-Gamo, M.; Ando, T. The role of chemisorbed oxygen on diamond surfaces for the dehydrogenation of ethane in the presence of carbon dioxide. J. Phys. Chem. B 2003, 107, 4048-4056. [CrossRef]

61. Zhao, X.; Wang, X. Oxidative dehydrogenation of ethane to ethylene by carbon dioxide over Cr/TS-1 catalysts. Catal. Commun . 2006, 7, 633-638. [CrossRef] 
62. Cheng, Y.; Lei, T.; Miao, C.; Hua, W.; Yue, Y.; Gao, Z. $\mathrm{Ga}_{2} \mathrm{O}_{3} / \mathrm{NaZSM}-5$ for $\mathrm{C}_{2} \mathrm{H}_{6}$ dehydrogenation in the presence of $\mathrm{CO}_{2}$ : Conjugated effect of silanol. Microporous Mesoporous Mater. 2018, 268, 235-242. [CrossRef]

63. Lei, T.Q.; Cheng, Y.H.; Miao, C.X.; Hua, W.M.; Yue, Y.H.; Gao, Z. Silica-doped $\mathrm{TiO}_{2}$ as support of gallium oxide for dehydrogenation of ethane with $\mathrm{CO}_{2}$. Fuel Process. Technol. 2018, 177, 246-254. [CrossRef]

64. Zhang, X.; Ye, Q.; Xu, B.; He, D. Oxidative dehydrogenation of ethane over Co-BaCO 3 catalysts using $\mathrm{CO}_{2}$ as oxidant: Effects of Co promoter. Catal. Lett. 2007, 117, 140-145. [CrossRef]

65. Koirala, R.; Safonova, O.V.; Pratsinis, S.E.; Baiker, A. Effect of cobalt loading on structure and catalytic behavior of $\mathrm{CoOx} / \mathrm{SiO}{ }_{2}$ in $\mathrm{CO}_{2}$-assisted dehydrogenation of ethane. Appl. Catal. A Gen. 2018, 552, 77-85. [CrossRef]

66. Porosoff, M.D.; Myint, M.N.Z.; Kattel, S.; Xie, Z.; Gomez, E.; Liu, P.; Chen, J.G. Identifying Different Types of Catalysts for CO 2 Reduction by Ethane through Dry Reforming and Oxidative Dehydrogenation. Angew. Chem. 2015, 127, 15721-15725. [CrossRef]

67. Gärtner, C.A.; VanVeen, A.C.; Lercher, J.A. Oxidative dehydrogenation of ethane: Common principles and mechanistic aspects. ChemCatChem 2013, 5, 3196-3217. [CrossRef]

68. Lobera, M.P.; Escolástico, S.; Serra, J.M. High ethylene production through oxidative dehydrogenation of ethane membrane reactors based on fast oxygen-ion conductors. ChemCatChem 2011, 3, 1503-1508. [CrossRef]

69. Rebeilleau-Dassonneville, M.; Rosini, S.; Van Veen, A.C.; Farrusseng, D.; Mirodatos, C. Oxidative activation of ethane on catalytic modified dense ionic oxygen conducting membranes. Catal. Today 2005, 104, 131-137. [CrossRef]

70. Akin, F.T.; Lin, Y.S. Selective oxidation of ethane to ethylene in a dense tubular membrane reactor. J. Memb. Sci. 2002, 209, 457-467. [CrossRef]

71. Champagnie, A.M.; Tsotsis, T.T.; Minet, R.G.; Webster, A.I. A high temperature catalytic membrane reactor for ethane dehydrogenation. Chem. Eng. Sci. 1990, 45, 2423-2429. [CrossRef]

72. Tonkovich, A.L.Y.; Zilka, J.L.; Jimenez, D.M.; Roberts, G.L.; Cox, J.L. Experimental investigations of inorganic membrane reactors: A distributed feed approach for partial oxidation reactions. Chem. Eng. Sci. 1996, 51, 789-806. [CrossRef]

73. Wang, H.; Tablet, C.; Schiestel, T.; Caro, J. Hollow fiber membrane reactors for the oxidative activation of ethane. Catal. Today 2006, 118, 98-103. [CrossRef]

74. Lobera, M.P.; Escolástico, S.; Garcia-Fayos, J.; Serra, J.M. Ethylene production by ODHE in catalytically modified $\mathrm{Ba}_{0.5} \mathrm{Sr}_{0.5} \mathrm{Co}_{0.8} \mathrm{Fe}_{0.2} \mathrm{O}_{3-\gamma}$ membrane reactors. ChemSusChem 2012, 5, 1587-1596. [CrossRef]

75. Liang, F.; He, G.; Jia, L.; Jiang, H. Cobalt-free dual-phase oxygen transporting membrane reactor for the oxidative dehydrogenation of ethane. Sep. Purif. Technol. 2019, 211, 966-971. [CrossRef]

76. Neal, L.M.; Yusuf, S.; Sofranko, J.A.; Li, F. Oxidative Dehydrogenation of Ethane: A Chemical Looping Approach. Energy Technol. 2016, 4, 1200-1208. [CrossRef]

77. Hu, J.; Galvita, V.V.; Poelman, H.; Detavernier, C.; Marin, G.B. Catalyst-assisted chemical looping auto-thermal dry reforming: Spatial structuring effects on process efficiency. Appl. Catal. B Environ. 2018, 231, 123-136. [CrossRef]

78. Hu, J.; Galvita, V.V.; Poelman, H.; Detavernier, C.; Marin, G.B. Pressure-induced deactivation of core-shell nanomaterials for catalyst-assisted chemical looping. Appl. Catal. B Environ. 2019, 247, 86-99. [CrossRef]

79. Poelman, H.; Galvita, V. V Intensification of Chemical Looping Processes by Catalyst Assistance and Combination. Catalysts 2021, 11, 266. [CrossRef]

80. Zeng, L.; Cheng, Z.; Fan, J.A.; Fan, L.S.; Gong, J. Metal oxide redox chemistry for chemical looping processes. Nat. Rev. Chem. 2018, 2, 349-364. [CrossRef]

81. Tian, X.; Zheng, C.; Li, F.; Zhao, H. Co and Mo Co-doped $\mathrm{Fe}_{2} \mathrm{O}_{3}$ for Selective Ethylene Production via Chemical Looping Oxidative Dehydrogenation. ACS Sustain. Chem. Eng. 2021, 9, 8002-8011. [CrossRef]

82. Yusuf, S.; Neal, L.; Bao, Z.; Wu, Z.; Li, F. Effects of Sodium and Tungsten Promoters on Mg6MnO8-Based Core-Shell Redox Catalysts for Chemical Looping-Oxidative Dehydrogenation of Ethane. ACS Catal. 2019, 9, 3174-3186. [CrossRef]

83. Burger, C.M.; Zhu, W.; Ma, G.; Zhao, H.; van Duin, A.C.T.; Ju, Y. Experimental and computational investigations of ethane and ethylene kinetics with copper oxide particles for Chemical Looping Combustion. Proc. Combust. Inst. 2021, 38, $5249-5257$. [CrossRef]

84. Chen, S.; Zeng, L.; Mu, R.; Xiong, C.; Zhao, Z.J.; Zhao, C.; Pei, C.; Peng, L.; Luo, J.; Fan, L.S.; et al. Modulating Lattice Oxygen in Dual-Functional Mo-V-O Mixed Oxides for Chemical Looping Oxidative Dehydrogenation. J. Am. Chem. Soc. 2019, 141, 18653-18657. [CrossRef]

85. Zhao, K.; He, F.; Huang, Z.; Wei, G.; Zheng, A.; Li, H.; Zhao, Z. Perovskite-type oxides LaFe1-xCoxO3 for chemical looping steam methane reforming to syngas and hydrogen co-production. Appl. Energy 2016, 168, 193-203. [CrossRef]

86. Novotný, P.; Yusuf, S.; Li, F.; Lamb, H.H. Oxidative dehydrogenation of ethane using $\mathrm{MoO}_{3} / \mathrm{Fe}_{2} \mathrm{O}_{3}$ catalysts in a cyclic redox mode. Catal. Today 2018, 317, 50-55. [CrossRef]

87. He, F.; Chen, J.; Liu, S.; Huang, Z.; Wei, G.; Wang, G.; Cao, Y.; Zhao, K. La1-xSrxFeO3 perovskite-type oxides for chemical-looping steam methane reforming: Identification of the surface elements and redox cyclic performance. Int. J. Hydrog. Energy 2019, 44, 10265-10276. [CrossRef]

88. Huang, Z.; Deng, Z.; Chen, D.; Wei, G.; He, F.; Zhao, K.; Zheng, A.; Zhao, Z.; Li, H. Exploration of Reaction Mechanisms on Hydrogen Production through Chemical Looping Steam Reforming Using $\mathrm{NiFe}_{2} \mathrm{O}_{4}$ Oxygen Carrier. ACS Sustain. Chem. Eng. 2019, 7, 11621-11632. [CrossRef] 
89. Gao, Y.; Haeri, F.; He, F.; Li, F. Alkali Metal-Promoted LaxSr2-xFeO4- $\delta$ Redox Catalysts for Chemical Looping Oxidative Dehydrogenation of Ethane. ACS Catal. 2018, 8, 1757-1766. [CrossRef]

90. Yusuf, S.; Neal, L.; Haribal, V.; Baldwin, M.; Lamb, H.H.; Li, F. Manganese silicate based redox catalysts for greener ethylene production via chemical looping-Oxidative dehydrogenation of ethane. Appl. Catal. B Environ. 2018, 232, 77-85. [CrossRef]

91. Yusuf, S.; Neal, L.M.; Li, F. Effect of Promoters on Manganese-Containing Mixed Metal Oxides for Oxidative Dehydrogenation of Ethane via a Cyclic Redox Scheme. ACS Catal. 2017, 7, 5163-5173. [CrossRef]

92. Yusuf, S.; Haribal, V.; Jackson, D.; Neal, L.; Li, F. Mixed iron-manganese oxides as redox catalysts for chemical looping-oxidative dehydrogenation of ethane with tailorable heat of reactions. Appl. Catal. B Environ. 2019, 257, 117885. [CrossRef]

93. Zhu, Y.; Shi, S.; Wang, C.; Hu, Y.H. Photocatalytic conversion of ethane: Status and perspective. Int. J. Energy Res. 2020, 44, 708-717. [CrossRef]

94. Zhang, R.; Wang, H.; Tang, S.; Liu, C.; Dong, F.; Yue, H.; Liang, B. Photocatalytic Oxidative Dehydrogenation of Ethane Using $\mathrm{CO}_{2}$ as a Soft Oxidant over $\mathrm{Pd} / \mathrm{TiO}_{2}$ Catalysts to $\mathrm{C}_{2} \mathrm{H}_{4}$ and Syngas. ACS Catal. 2018, 8, 9280-9286. [CrossRef]

95. Han, B.; Wei, W.; Li, M.; Sun, K.; Hu, Y.H. A thermo-photo hybrid process for steam reforming of methane: Highly efficient visible light photocatalysis. Chem. Commun. 2019, 55, 7816-7819. [CrossRef]

96. Wang, S.; Luo, J.L.; Sanger, A.R.; Chuang, K.T. Performance of ethane/oxygen fuel cells using yttrium-doped barium cerate as electrolyte at intermediate temperatures. J. Phys. Chem. C 2007, 111, 5069-5074. [CrossRef]

97. Ding, D.; Zhang, Y.; Wu, W.; Chen, D.; Liu, M.; He, T. A novel low-thermal-budget approach for the co-production of ethylene and hydrogen via the electrochemical non-oxidative deprotonation of ethane. Energy Environ. Sci. 2018, 11, 1710-1716. [CrossRef]

98. Lin, J.Y.; Shao, L.; Si, F.Z.; Liu, S.B.; Fu, X.Z.; Luo, J.L. Co2CrO4 Nanopowders as an Anode Catalyst for Simultaneous Conversion of Ethane to Ethylene and Power in Proton-Conducting Fuel Cell Reactors. J. Phys. Chem. C 2018, 122, 4165-4171. [CrossRef]

99. Liu, S.; Liu, Q.; Fu, X.Z.; Luo, J.L. Cogeneration of ethylene and energy in protonic fuel cell with an efficient and stable anode anchored with in-situ exsolved functional metal nanoparticles. Appl. Catal. B Environ. 2018, 220, 283-289. [CrossRef]

100. Liu, S.; Chuang, K.T.; Luo, J.L. Double-Layered Perovskite Anode with in Situ Exsolution of a Co-Fe Alloy to Cogenerate Ethylene and Electricity in a Proton-Conducting Ethane Fuel Cell. ACS Catal. 2016, 6, 760-768. [CrossRef] 